\title{
A RARE EOCENE WATER LILY (NYMPHAEA) FOSSIL FROM CHEILE BACIULUI (CLUJ-NAPOCA, ROMANIA)
}

\section{LÁSZLÓ LÓRÁNT FEHÉR*}

\begin{abstract}
A rare water lily (Nymphaceae) fossil is reported from the Late Eocene (Priabonian) deposits from Cheile Baciului limestone quarry (Cluj-Napoca, Romania). The remains consist of a piece of rhizome and a few root impressions preserved on the bearing rock. The fossil was identified as belonging to Nymphaea cf. alba Linnaeus. The rhizome of this species has never been found together with root impressions in Transylvania, being a very rare find even in Central Europe.
\end{abstract}

Keywords: plant fossil (Nymphaea); Priabonian; Cheile Baciului; NW Romania.

\section{INTRODUCTION}

Late Eocene plant fossils are rarely recorded from NW Transylvania. An overview of the Eocene floras of Transylvania is made by PETRESCU \& GIVULESCU (1987). They analyzed the fossil floras identified in the Lutetian of Leghia (Cluj), early Priabonian of Gârbou (Cluj) and Morlaca (Huedin), as well as Glod (Jibou). The lack of palaeobotanical information lies in the sedimentary conditions in this part of Romania, during the Eocene.

One of the most comprehensive macroflora for the whole Romanian Eocene was described from the early Priabonian of Gârbou (Cluj), which leads to distinguish several plant communities for the Eocene of NW Transylvania (op. cit.). Nymphacean remains were identified within the hygrophytic (Castalites rhizomes), and swamp communities (Nymphaea odorata, Nuphar luteum, Nyphoides aquatica).

An occasional field trip in the Cluj-Napoca area resulted in the discovery of a unique water lily (Nymphaea cf. alba LINNAEUS) fossil. The aim of this article is to give a description of the fossil and to present the occurrence of the taxon in Central Europe.

\section{GEOGRAPHICAL AND GEOLOGICAL SETTING}

The fossiliferous site is located in a small creek situated on the left side of the Valea Lungă Valley in Cheile Baciului (CB) desserted limestone quarry (7 km NW from Cluj-Napoca). On the Cheile Baciului profile, there are exposed from bottom to top the following units (deepening upward sequence):

-The top of the Valea Nadasului Fm., continental (alluvial) red bluish spotted silty clays (lower Priabonian) - $4 \mathrm{~m}$.

-Jebucu member, evaporitic sequence (upper Priabonian) - $0.4 \mathrm{~m}$.

\footnotetext{
* "Babeș-Bolyai" University, Department of Geology, 1 Kogă Iniceanu str., 3400 Cluj-Napoca, Romania
} 


\section{LÁSZLÓ LÓRÁNT FEHÉR}

-Cluj Fm., interbedded limestones, marls and calcarenites (upper Priabonian) $-18 \mathrm{~m}$.

-The lower section of Brebi Fm. (upper Priabonian) - $3 \mathrm{~m}$. The upper limit represents a major erosional discontinuity, followed by a transgresive sequence.

-The Dej tuffaceous Fm. (Badenian) - $10 \mathrm{~m}$.

The micaceous silto-arenitic stratum from which the fossil was recovered represents the top of the Cluj Limestone Fm., exposed immediately under the Brebi Marl Fm., belonging to NP 20 (MÉSZÁROS, 1992). The sedimentation of this unit took place in a shallow marine environment.

\section{DESCRIPTION OF MATERIAL}

Water lily rhizome fragment, including root imprints (Palaeontological Museum of Babes-Bolyai University, Cluj, MBT nr. 730). The length of the rhizome is $81 \mathrm{~mm}$ and the scars left by the fallen leaves are clearly visible (PI. I., fig. 1.). They have a rhombic shape and are packed closely in oblic rows, completely covering one side of the rhizome. The scars left by the roots can also be observed on the other side of the rhizome (PI. I., fig. 2.). These are also clearly visible, being restrained to three spots. The distance between the spots is of $15 \mathrm{~mm}$ and the surface of the rhizome is covered by leafscars here. The rootscars have a rounded shape and they are irregularly arranged in the spots.

On the rhizome bearing piece of rock, four root imprints can be observed. These have lengths of $5-45 \mathrm{~mm}$, widths of $4-5 \mathrm{~mm}$, and they are segmented. The length of these segments is also varying between 1-3 mm (PI. I., fig. 3.). This is a unique condition in Romania and even in Central Europe, because usually the roots are not preserved, because they are very fragile.

The rhizome and root morphology allowed to establish the appartenance to the Nymphaea cf. alba species.

\section{DISCUSSION AND CONLUSION:}

Untill present momment, only one rhizome with attached single root is reported from the Late Eocene or lowermost Oligocene of Budakeszi in Hungary (BOROS, 1927). The length of the root is only $10 \mathrm{~mm}$, being much shorter than the root imprints preserved on the CB specimen.

A Nymphaea rhizome was also found near Poprad (Slovakia). This specimen was preserved in Pleistocene freshwater limestone, no roots being attached to it (TULOGDY J., 1938).

In Romania, TULOGDY (1938) published for the first time a rhizome fossil alocated to Castalia (cf. Nymphaea) alba LINNAEUS, found near Suceag (NW from Cluj-Napoca). This fossil comes from the same Cluj Limestone Fm. in which the CB specimen was found. This author supposed that the water lilies were populating some lakes situated near the seashore, which were in connection with the sea through some short riverchannels. 
SZAKÁCS (1957) mentioned the occurence of the Castalia (Nymphaea) fossil in the Cluj Fm. near Suceag, but he gave neither a description nor a figure of the fossil. Another occurence of Nymphaea rhizome was reported from the upper section of Cluj Limestone Fm. exposed in the Somesul Mic riverbed (FUCHS, in script). Neither of the above mentioned authors had reported root imprints.

There is a rich fossil record of the Nympheacea species in Western Europe including not only rhizomes but also leaves, flowers and seeds (TULOGDY, 1938).

In conclusion, this discovery is important because there are preserved the root imprints together with the actual rhizome mold. Such preservational condition of Eocene water lily rhizomes is unique being the first find from the Tertiary of Romania.

\section{REFERENCES}

Boros Á., (1927), Paleogén Castalia-rhizóma fosszilia hazánkból. Földt. közl., LVI., p.126127, Budapest.

Mészáros, N., (1992), Nannofossil zones in the Paleogene and Miocene Deposits of the Transylvanian Basin. Knihovnicka ZPN, 14/2., p. 87-92

Petrescu, I., Givulescu, R. (1987), Considerations on the Eocene vegetation in the NorthWestern part of the Basin of Transylvania. The Eocene of the Transylvanian Basin, p. 59-70, Cluj-Napoca

Szakács I., (1957), Adatok a szucsági felső dúrvamészkőszint puhatestű faunájának és paleoökológiai viszonyainak ismeretéhez. Tudományos Diákkörök Évkönyve, 195556 , p. 154-169, Kolozsvár.

Tulogdy J., (1938), Castalia kövület. Különlenyomat a Szádeczky-Kardoss Gyula emlékkönyvböl, Kolozsvár.

\section{EXPLANATION OF PLATES}

\section{Plate I.}

1. - Nymphaea cf. alba LINNAEUS, rhizome with the leafscars (scale bar in centimeter in all figures).

2. - Nymphaea cf. alba LINNAEUS, rhizome with the leafscars and rootscars.

3. - rhizome and roots (near the arrows) imprints of the Nymphaea cf. alba LINNAEUS. 


\section{PI. I.}
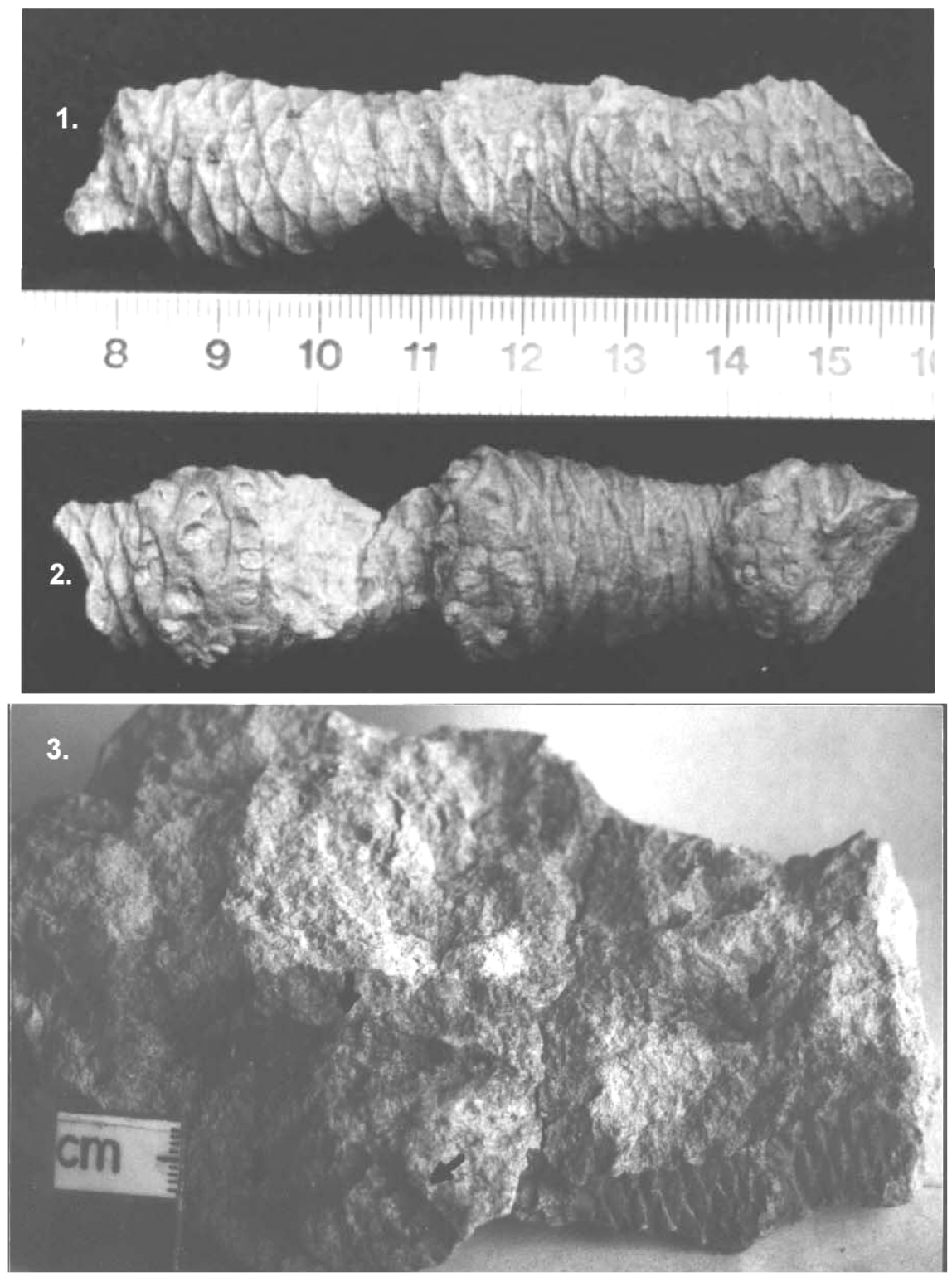